\title{
Synthesis, Characterization and Anticorrosion Studies of New Homobimetallic Co(II), Ni(II), Cu(II), and Zn(II) Schiff Base Complexes
}

\author{
A. M. Nassar ${ }^{1}$ A. M. Hassan ${ }^{1}$ M. A. Shoeib ${ }^{2}$ A. N. El kmash ${ }^{1}$
}

Received: 14 March 2015/Revised: 10 May 2015/Accepted: 4 June 2015/Published online: 12 June 2015

(c) Springer International Publishing AG 2015

\begin{abstract}
New homobinuclear $\mathrm{Co}(\mathrm{II}), \mathrm{Ni}(\mathrm{II}), \mathrm{Cu}(\mathrm{II})$, and $\mathrm{Zn}$ (II) complexes with Schiff base $\left(\mathbf{H}_{\mathbf{2}} \mathbf{L}, \mathbf{1}\right)$ have been synthesized and investigated using physicochemical techniques viz. IR, ${ }^{1} \mathrm{H}$ NMR, ${ }^{13} \mathrm{C}$ NMR, ESR, UV-Visible spectrometric methods, thermal gravimetric analysis, and magnetic moment measurements. The corrosion inhibition studies of the compounds on mild steel in $(0.5 \mathrm{M}) \mathrm{HCl}$ have been investigated by weight loss, potential dynamics polarization, and scanning optical microscope. The adsorption of compounds was founded to obey the Langmuir adsorption isotherm model showing mixed type inhibition behavior. The in vitro antibacterial studies of the complexes against sulfate-reducing bacteria proved them as growth inhibiting agents.
\end{abstract}

Keywords Schiff base $\cdot$ Binuclear complexes $\cdot$ Mild steel $\cdot$ Acid solution $\cdot$ Polarization $\cdot$ Microbiological corrosion

\section{Introduction}

Corrosion is the destructive attack of metals by its environment and destruction of metal due to heterogeneous chemical reaction which is called the chemical corrosion [1]. The mild steel has wide applications in various

A. M. Nassar

nassar_tanta@yahoo.com

1 Chemistry Department, Faculty of Science, Al-Azhar University, Nasr City, Cairo, Egypt

2 Central of Metallurgical Research and Development Institute (CMRDI), Cairo, Egypt industries as construction materials for reactors, heat exchange, boilers, storage tanks, and oil and gas transport pipelines due to its mechanical properties and low cost [2]. The use of corrosion inhibitors is one of the most practical methods for the protection of metals against corrosion in acidic media [3]. The interaction between the metal surface and hetero atoms like nitrogen, oxygen, and sulfur plays an important role in the corrosion inhibition due to the free electron pairs that possess [4-7]. Moreover, the compounds that contain $\pi$ bonds generally exhibit good inhibition efficiency supplying electrons via the $\pi$-orbitals [8]. Due to the presence of azomethane $(\mathrm{C}=\mathrm{N})$ group in the Schiff base molecules, they should be good corrosion inhibitors. Some Schiff bases and transition metal complexes have been reported as effective corrosion inhibitors for mild steel, aluminum, copper, and zinc in acid media [9-15]. The effect of diacetylmonoxime derivative on the corrosion of metal in acidic media was reported [16]. Much corrosions of industrial equipments have been ascribed to microbiologically influenced corrosion (MIC) [17]. Sulfate-reducing bacteria (SRB) are the main reason to cause the MIC by accelerating corrosion rate, inducing stress corrosion, and pitting corrosion [18]. The biocides can be used as SRB growth inhibitors to protect the metals from microbial corrosion [19].

In this study, we synthesized and characterized Cobal$\mathrm{t}(\mathrm{II})$, Nickel(II), Copper(II), and Zinc(II) complexes with Schiff base; Bis(diacetylmonoxime)biphenyl-3,3'-dimethoxy-4,4'-diamine Schiff base $\left(\mathbf{H}_{\mathbf{2}} \mathbf{L}, \mathbf{1}\right)$ which is synthesized from the condensation of o-Dianisidine with Diacetylmonoxime and studied the effect of the compounds as corrosion inhibitors of carbon steel in $0.5 \mathrm{M}$ $\mathrm{HCl}$. The gravimetric and electrochemical techniques such as weight loss and potentiodynamic polarization measurements were used in this study. The scanning optical 
microscope was used to explain adsorption of inhibitors on the surface of metal. Some isotherm was used to describe the adsorption behavior of the compounds understudied. Also, antibacterial activity against SRB of compounds was studied.

\section{Experimental}

\subsection{Materials and Methods}

The analytical reagent grade (AR) o-Dianisidine, Diacetylmonoxime, $\mathrm{CoCl}_{2} \cdot 6 \mathrm{H}_{2} \mathrm{O}, \mathrm{NiCl}_{2} \cdot 6 \mathrm{H}_{2} \mathrm{O}, \mathrm{CuCl}_{2}$. $2 \mathrm{H}_{2} \mathrm{O}, \mathrm{ZnCl}_{2} \cdot 2 \mathrm{H}_{2} \mathrm{O}$ are Aldrich or Merck chemicals. Organic solvents used (methanol, ethanol, diethyl ether, and acetone) were HPLC or extra-pure grades and were used without further purification. The electrolyte solution was $0.5 \mathrm{M} \mathrm{HCl}$, prepared from analytical grade $\mathrm{HCl}$ and distilled water. All corrosion tests were performed at room temperature. The mild steel working electrode specimens have the following composition, $\mathrm{C}=0.066 \%, \mathrm{Mn}=$ $0.3 \%, \quad \mathrm{P}=0.01 \%, \quad \mathrm{~S}=0.02 \%, \quad \mathrm{Cr}=0.026 \%$, $\mathrm{Cu}=0.02 \%$, and $\mathrm{Fe}=99.5 \%$ and using $2 \mathrm{~cm}^{2}$ coupons of same sample material. The weight loss and Polarization measurements were performed on mild steel in deaerated $0.5 \mathrm{M} \mathrm{HCl}$ solution with and without Schiff base and its complex additives within the concentration ranges $1,3,5$, and $7 \times 10^{-4} \mathrm{Mol} / \mathrm{dm}^{3}$. Weight loss experiments were carried out electronically at room temperature. After recording the initial weights of mild steel specimens on a Mettler Toledo, Japan AB 135-S/FACT, single pan analytical balance, (with a precision of $0.01 \mathrm{mg}$ ), they were kept in different isolated chamber (perfectly insulated from each other) for $48 \mathrm{~h}$ of exposure time in different concentrations 1, 3, 5, $7 \times 10^{-4} \mathrm{Mol} / \mathrm{dm}^{3}$. A uniform thin film of compounds was adsorbed on to the metal coupons after $48 \mathrm{~h}$ of exposure. Then these coupons were taken out from the chamber and washed initially under the running tap water. Loosely adhering corrosion products were removed with the help of rubber cork and the specimen was again washed thoroughly with triple distilled water and acetone and dried with hot air blower and then weighed again. The electrochemical behavior of the mild steel sample in inhibited and non-inhibited solution was studied by recording anodic and cathodic potentiodynamic polarization curves. Measurements were performed in the $0.5 \mathrm{M}$ $\mathrm{HCl}$ solution containing different concentrations of the tested inhibitor by changing the electrode potential automatically from -250 to $+500 \mathrm{mV}$ versus corrosion potential at a scan rate of $1 \mathrm{mV} \mathrm{s}^{-1}$. The Stock solutions of the Schiff base and its complexes were made in 10:1 ratio of water: DMF mixture by volume to ensure solubility. The optical microscope images were taken to establish the interaction of inhibitors with metal surface in acid medium. The surface images of carbon steel samples were examined by optical microscope after the sample is immersed in $0.5 \mathrm{M} \mathrm{HCl}$ for $48 \mathrm{~h}$ in the absence and presence of inhibitors. The antibacterial activity of compounds was carried out at National Research Center (NRC). The incubation period was for seven days at $30^{\circ} \mathrm{C}$.

\subsection{Instruments}

Elemental analysis ( $\% \mathrm{C}, \% \mathrm{H}$, and $\% \mathrm{~N})$ and mass spectra were determined in the Micro Analytical Laboratory. Magnetic susceptibility measurements were carried out at room temperature on a Sherwood Scientific Magnetic Balance. Electronic spectra were measured in range $(195-1100 \mathrm{~nm})$ using a Perkin-Elmer lambda $35 \mathrm{UV}-\mathrm{Vis}$ Spectrometer. Infrared (IR) spectra were recorded using $\mathrm{KBr}$ pellets on a Perkin-Elmer 1430 Spectrometer for the region $\left(200-4000 \mathrm{~cm}^{-1}\right)$. ${ }^{1} \mathrm{H}$ NMR and ${ }^{13} \mathrm{C}$ NMR spectra were recorded on GEMINI-300BB NMR $500 \mathrm{MHz}$ spectrometer. The thermo gravimetric analysis (TGA) for complexes were obtained at a heating rate of $10{ }^{\circ} \mathrm{C} / \mathrm{min}$ and flowing nitrogen atmosphere over a temperature range of $20-800{ }^{\circ} \mathrm{C}$. The electron spin resonance (ESR) spectra were recorded on Bruker EMX spectrometer working in expand $9.7 \mathrm{GHz}$ with $100 \mathrm{kHz}$ frequency and microwave power $1 \mathrm{MW}$ and modulation amplitude 4Gauses. Potentiodynamics polarization measurement was carried out using Autolab-PGSTAT302 N-HP and using a glassy carbon working electrode, platinum wire auxiliary electrode, and an $\mathrm{Ag} / \mathrm{AgCl}$ as reference electrode and Scanning Optical Microscope (SOM) using ZEISS, Axiovert 40 mat microscope.

\subsection{Synthesis of Schiff Base Ligand $\mathrm{H}_{2} \mathrm{~L}, 1$}

Ligand (L) is prepared by mixing (2:1) molar ratio of diacetylmonoxime $(1.011 \mathrm{gm}, 0.01 \mathrm{~mol})$ and o-dianisidine $(1.22 \mathrm{~g}, 0.005 \mathrm{~mol})$ in $50 \mathrm{ml}$ hot etathanol solution and refluxing the mixture for $3 \mathrm{~h}$ with continous stirring. Upon cooling, black oily residue that remains is treated with petroleum ether $(20 \mathrm{ml})$ with vigorous stirring for $30 \mathrm{~min}$. The contents are collected in beaker and allowed to form precipitate. The obtained black precipitate was filtered off, and recrystallized from DMF to give deep brown crystals. Finally the crystals were washed several times with diethyl ether and then air dried. The purity of the ligand was checked by TLC technique. M.p. $155^{\circ} \mathrm{C}$, M. Wt. 410.4, Yield (81.2 \%), Anal. Calc. for $\mathrm{C}_{22} \mathrm{H}_{26} \mathrm{~N}_{4} \mathrm{O}_{4}: \mathrm{C}, 64.39 ; \mathrm{H}, 6.34 ; \mathrm{N}, 13.65 \%$, Found: $\mathrm{C}, 64.47 ; \mathrm{H}, 6.27$; N, $13.84 \%$; main IR Peaks $\left(\mathrm{KBr}, \mathrm{cm}^{-1}\right)$ : $v(\mathrm{OH}) 3441, v(\mathrm{C}=\mathrm{N}) 1620$. 


\subsection{Synthesis of the Metal Complexes}

A sample of hydrated $\mathrm{MCl}_{2}(\mathrm{M}=\mathrm{Co}, \mathrm{Ni}, \mathrm{Cu}$, and $\mathrm{Zn})$ $(2.0 \mathrm{mmol})$ was dissolved in hot ethanol solution $(30 \mathrm{ml})$, and was added to an ethanolic $(30 \mathrm{ml})$ solution of $\mathbf{H}_{2} \mathbf{L}$ $(1.0 \mathrm{mmol})$. The reaction mixture was heated under reflux for $3 \mathrm{~h}$. The fine solid complexes formed were collected by filtration, washed with hot ethanol, hot water, and ether, and then, air dried. The complexes are stable in air.

\subsubsection{The Complex, $\mathrm{Co}_{2} \mathrm{~L}\left(\mathrm{H}_{2} \mathrm{O}\right)_{2}(\mathrm{Cl})_{2} \cdot 2 \mathrm{H}_{2} \mathrm{O}$ (2)}

Dark brown solid. M.p $>300{ }^{\circ} \mathrm{C}$; M. Wt. 670.9; Anal. Calc for $\mathrm{C}_{22} \mathrm{H}_{34} \mathrm{Co}_{2} \mathrm{~N}_{4} \mathrm{O}_{8} \mathrm{Cl}_{2}$ : C,39.34; H,5.06; N,8.34; Co, $17.58 \%$; Found: C, 39.5; H, 5.12; N, 8.4; Co, $16.9 \%$; main IR Peaks $\left(\mathrm{KBr}, \mathrm{cm}^{-1}\right): v(\mathrm{C}=\mathrm{N}) 1608$.

\subsubsection{The Complex, $\mathrm{Ni}_{2} \mathrm{~L}\left(\mathrm{H}_{2} \mathrm{O}\right)_{2}(\mathrm{Cl})_{2} \cdot 2 \mathrm{H}_{2} \mathrm{O}$ (3)}

Dark brown solid. M.p $>300{ }^{\circ} \mathrm{C}$; M. Wt. 670.38; Anal. Calc for $\mathrm{C}_{22} \mathrm{H}_{34} \mathrm{Ni}_{2} \mathrm{~N}_{4} \mathrm{O}_{8} \mathrm{Cl}_{2}$ : C,39.38; H,5.07; N,8.35; Ni, $17.5 \%$; Found: C, 39.4; H, 5.14; N, 8.4; Ni, $17.0 \%$; main IR Peaks $\left(\mathrm{KBr}, \mathrm{cm}^{-1}\right): \mathrm{v}(\mathrm{C}=\mathrm{N}) 1608$.

\subsubsection{The Complex, $\mathrm{Cu}_{2} \mathrm{~L}\left(\mathrm{H}_{2} \mathrm{O}\right)_{2}(\mathrm{Cl})_{2} \cdot 2 \mathrm{H}_{2} \mathrm{O}(4)$}

Black solid. M.p. $295{ }^{\circ} \mathrm{C}$; M. Wt. 680.8; Anal. Calc for $\mathrm{C}_{22} \mathrm{H}_{34} \mathrm{Cu}_{2} \mathrm{~N}_{4} \mathrm{O}_{8} \mathrm{Cl}_{2}$ : C,38.8; H,4.99; N,8.23; Cu, $18.68 \%$; Found: C, 38.9; H, 5.03; N, 8.29; Cu, $17.9 \%$; main IR Peaks $\left(\mathrm{KBr}, \mathrm{cm}^{-1}\right): v(\mathrm{C}=\mathrm{N}) 1598$.

\subsubsection{The Complex, $\mathrm{Zn}_{2} L\left(\mathrm{H}_{2} \mathrm{O}\right)_{2}(\mathrm{Cl})_{2} \cdot 2 \mathrm{H}_{2} \mathrm{O}(5)$}

Brown solid. M.p $>300{ }^{\circ} \mathrm{C}$; M. Wt. 683.8; Anal. Calc for $\mathrm{C}_{22} \mathrm{H}_{34} \mathrm{Zn}_{2} \mathrm{~N}_{4} \mathrm{O}_{8} \mathrm{Cl}_{2}$ : C,38.6; H,4.97; N,8.2; Zn, $19.1 \%$; Found: C, 38.7; H, 4.96; N, 8.28; Zn, $18.9 \%$; main IR Peaks $\left(\mathrm{KBr}, \mathrm{cm}^{-1}\right): v(\mathrm{C}=\mathrm{N}) 1610$.

\subsection{Antibacterial Assay}

The enrichment of (SRB) and biological assay was carried out using most probable number (MPN) technique [20].

\section{Results and Discussion}

The present Schiff base $\mathbf{H}_{2} \mathbf{L}$, Fig. 1 was prepared by refluxing an ehanolic solutions of o-dianisidine with diacetyl monoxime in (1:2) molar ratio, respectively. The structure of formed Schiff base was established by IR, ${ }^{1} \mathrm{H}$ and ${ }^{13} \mathrm{C}$ NMR, mass, and UV-Vis spectra as well as elemental analysis. All complexes were prepared by direct reaction of $\mathbf{H}_{2} \mathbf{L}$ with metal chlorides in (1:2) molar ratio, respectively.

\subsection{Characterization of Schiff Base Ligand $\left(\mathrm{H}_{2} \mathrm{~L}\right)$}

The infrared spectrum of the Schiff base ligand $\mathbf{H}_{2} \mathbf{L}$ in the region $200-4000 \mathrm{~cm}^{-1}$ shows a medium absorption band at $1620 \mathrm{~cm}^{-1}$ assigned to the $v(\mathrm{C}=\mathrm{N})$ azomethine stretching vibrations, indicating the formation of the Schiff base linkage. Furthermore, the absence of $\mathrm{C}=\mathrm{O}$ and $\mathrm{NH}_{2}$ stretching vibration in the spectra of the ligand related to aldehyde and amine, respectively, indicate the occurrence of Schiff base condensation [21]. The band observed at $1504 \mathrm{~cm}^{-1}$ was assigned to $v(\mathrm{C}=\mathrm{N})$ oxime [22]. The spectrum shows a broad medium intensity band that occurs at $3441 \mathrm{~cm}^{-1}$ which is assigned to the oxime $\mathrm{NOH}$ group. Also, the two weak bands at $2840-2960 \mathrm{~cm}^{-1}$ region can be taken as evidence for the presence of intramolecular hydrogen bond $\mathrm{OH} . . . \mathrm{N}=\mathrm{C}[23,24]$. As the hydrogen bond becomes stronger, the bandwidth increases, however, this band is sometimes not detected. Hydrogen bonds in these Schiff bases are usually very strong while the ligands are relatively planar with adequate intramolecular distance that favors intramolecular hydrogen bond formation. The methoxy groups as electron-donating groups increase the electron density on the hydroxyl oxygen making the $\mathrm{H}-\mathrm{O}$ bond stronger; the absorption usually appears as a broad band in the IR spectrum. The two weak intensity bands at 3090 and $2860 \mathrm{~cm}^{-1}$ correspond to $v(\mathrm{C}-\mathrm{H})_{\mathrm{ar}}$ and $\mathrm{v}(\mathrm{C}-\mathrm{H})_{\text {aliph }}$ stretching vibrations. The stretching vibration observed at $1272 \mathrm{~cm}^{-1}$ is due to $v(\mathrm{C}-\mathrm{O})$ [25]. Also, the strong band at $1030 \mathrm{~cm}^{-1}$ is assigned to $v(\mathrm{NO})$ oxime [26]. The $(\mathrm{Ph}-\mathrm{N})$ gives medium intensity band at $1122 \mathrm{~cm}^{-1}$. The ${ }^{1} \mathrm{H}$ NMR spectrum (Fig. 2a, b) shows that signals lying at the range $11.3 \mathrm{ppm}$ are due to the resonance hydroxyl groups; the signals of $\mathrm{OH}$ groups lying at the higher field side can be attributed to the contribution of the $\mathrm{OH}$ group intramolecular and intermolecular hydrogen bonds; the addition of $\mathrm{D}_{2} \mathrm{O}$ to the previous solution results in the disappearance of the signal due to proton exchange [27]. Also, the multiple signals lying in the range of 6.6-7.2 ppm [28] are due to the resonance of aromatic protons. The methoxy groups protons appear signal at $3.8 \mathrm{ppm}$ [29].

The ${ }^{13} \mathrm{C}$ NMR spectrum of the free ligand was recorded in DMSO-d6. The spectrum showed signals at $129 \mathrm{ppm}$ (C1-ipso), 108 ppm(C2-H), 114 ppm(C3-H), 118 ppm(C4ipso), 135 ppm(C5-ipso), 146.5(C6-ipso), 55 ppm(C9-H), and $38,40 \mathrm{ppm}(\mathrm{C} 7$ and $\mathrm{C} 8)$. The electronic spectrum of the ligand displaying bands at 314 and $360 \mathrm{~nm}$ are attributed to intraligand $\pi-\pi^{*}$ and $n-\pi^{*}$ transitions for the benzene ring and azomethine group [30]. The mass spectrum of the free Schiff base ligand (Fig. 3) shows its molecular ion peak at 
Fig. 1 The proposed Structure of Schiff base ligand $\mathbf{H}_{\mathbf{2}} \mathbf{L}$

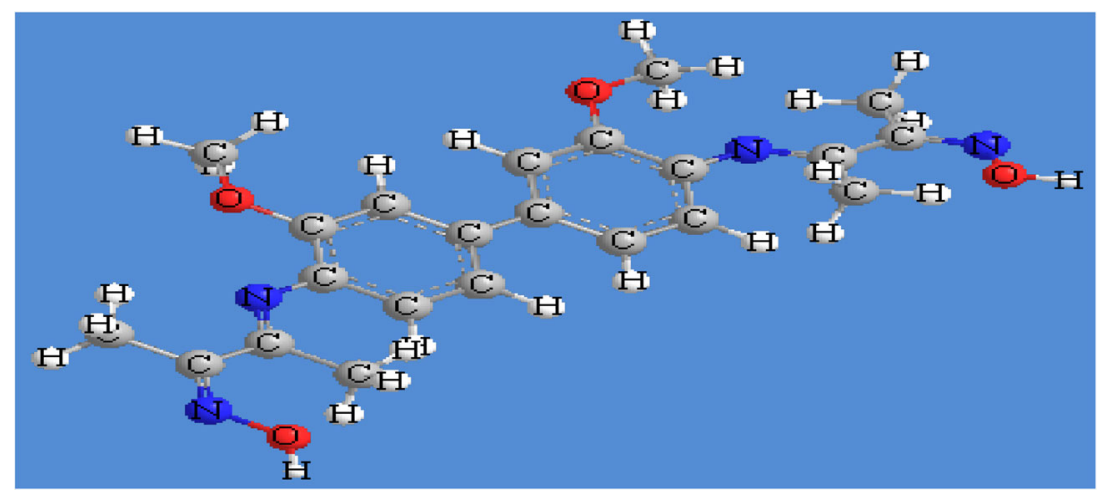

$m / e=411$ which matches with a formula weight (Scheme 1).

\subsection{Characterization of Complexes}

\subsubsection{IR Spectra}

The infrared spectra of the complexes were collected in a Table 1 and compared with that of free ligand to give some information about the bonding in the complexes. The band in the IR spectrum of the ligand at $1620 \mathrm{~cm}^{-1}$ is found to be shifted to lower frequencies $1598-1608 \mathrm{~cm}^{-1}$ in the spectra of the complexes, indicated donation of the lone pair of electrons on azomethine nitrogen to metal center [31]. Moreover the new band in the far infrared spectra of the complexes in the range $584-615 \mathrm{~cm}^{-1}$ is assigned to the $v \mathrm{M}-\mathrm{N}$. Deprotonation of all hydroxyl functions is confirmed by the lack of Oxime $\mathrm{N}-\mathrm{O}-\mathrm{H}$ and shift of $v \mathrm{~N}-\mathrm{O}$ to higher wave number to about $1059-1063 \mathrm{~cm}^{-1}$ but appeared in free ligand at $1030 \mathrm{~cm}^{-1}$, indicating the participation with the metal ion as $-\mathrm{O}^{-}$. The broadening bands observed in the spectra of complexes in the range $3377-3488 \mathrm{~cm}^{-1}$ considerable support the presence of water molecules in the complexes [24, 32, 33]. The weak bands appeared in the far IR spectra between $615-660 \mathrm{~cm}^{-1}$ were attributed to $v \mathrm{M}-\mathrm{O}$. The far infrared spectra of the complexes show weak bands in the range $312-318 \mathrm{~cm}^{-1}$ ascribable to $v \mathrm{M}-\mathrm{Cl}$.

\subsubsection{UV-Vis Spectra}

The electronic spectrum of Co(II) complex 2, Fig. 4 shows low intensity shoulders at 569 and 670. The former bands are probably due to ${ }^{4} \mathrm{~A}_{2}(\mathrm{~F}) \rightarrow{ }^{4} \mathrm{~T}_{1}(\mathrm{P})$ and ${ }^{4} \mathrm{~A}_{2}(\mathrm{~F}) \rightarrow{ }^{4} \mathrm{~T}_{1}$ (F) which indicates the tetrahedral geometry of this complex. Magnetic moment (4.2 B.M) confirms the tetrahedral geometry of the ligand around $\mathrm{Co}^{+2}$ ions [34]. The spectrum of the $\mathrm{Ni}$ (II) complex 3 shows a very broad band at $520 \mathrm{~nm}$ containing the ${ }^{3} \mathrm{~T}_{1}(\mathrm{~F}) \rightarrow{ }^{3} \mathrm{~T}_{1}(\mathrm{P})$ which suggests that the coordination geometry at the metal atom could be distorted from the tetrahedral configuration of this complex. The magnetic moment (3.6 B.M) indicates the tetrahedral geometry [35]. The broad band at $528 \mathrm{~nm}$ in the spectrum of $\mathrm{Cu}$ (II) complex 4 , as well as the $\mu_{\text {eff }}$ value (1.85 B.M) is corresponding to the tetrahedral of the copper complex [36]. Finally, the electronic absorption spectrum of $\mathrm{Zn}$ (II) complex 5 shows an absorption band at $425 \mathrm{~nm}$ attributed to the LMCT transition, which is compatible with this complex having an tetrahedral structure; the diamagnetic behavior is due to $\mathrm{d}^{10}$ configuration of $\mathrm{Zn}^{+2}$ ions [37].

\subsubsection{NMR $\left({ }^{1} \mathrm{H}\right.$ and $\left.{ }^{13} \mathrm{C}\right)$}

The ${ }^{1} \mathrm{H}$ NMR spectrum of the zinc complex 5 is recorded in DMSO-d6 at room temperature. In the spectrum of the zinc complex the hydroxyl oxime proton signals observed at $\delta$ $11.3 \mathrm{ppm}$ in the spectrum of the free ligand was found to be absent, confirming the subsequent involvement of deprotonated hydroxyls in chelation to the metal ions [38]. The broad signal appeared at $\delta 4.9 \mathrm{ppm}$, was not found in the spectrum of the free ligand due to the resonance of protons of coordinated water molecules [disappeared after addition of $\mathrm{D}_{2} \mathrm{O}$ due to proton exchange] [21]. The ${ }^{13} \mathrm{C}$ NMR spectrum of zinc complex showed chemical shift to higher value at $146.9 \mathrm{ppm}$ (C6-ipso) and $130.2 \mathrm{ppm}$ (C1ipso) in comparison with the signal of free ligand suggest that coordination through nitrogen of azomethine $(\mathrm{C}=\mathrm{N})$ and oxygen of oxime $(\mathrm{C}=\mathrm{N}-\mathrm{OH})$ group. No changes in signals of other carbon atoms are detected.

\subsubsection{Electron Spin Resonance (ESR) Spectra}

The electron spin resonance (ESR) spectrum of $\mathrm{Cu}$ (II) complex 4; Fig. 5 in solid state gives axial signal shape and have symmetric bands with two $g$ values, $g_{\|}=2.28$, $g_{\perp}=2.04$. These values suggest a tetrahedral stereochemistry for the complex. The average $g$ value equals 2.12 was 

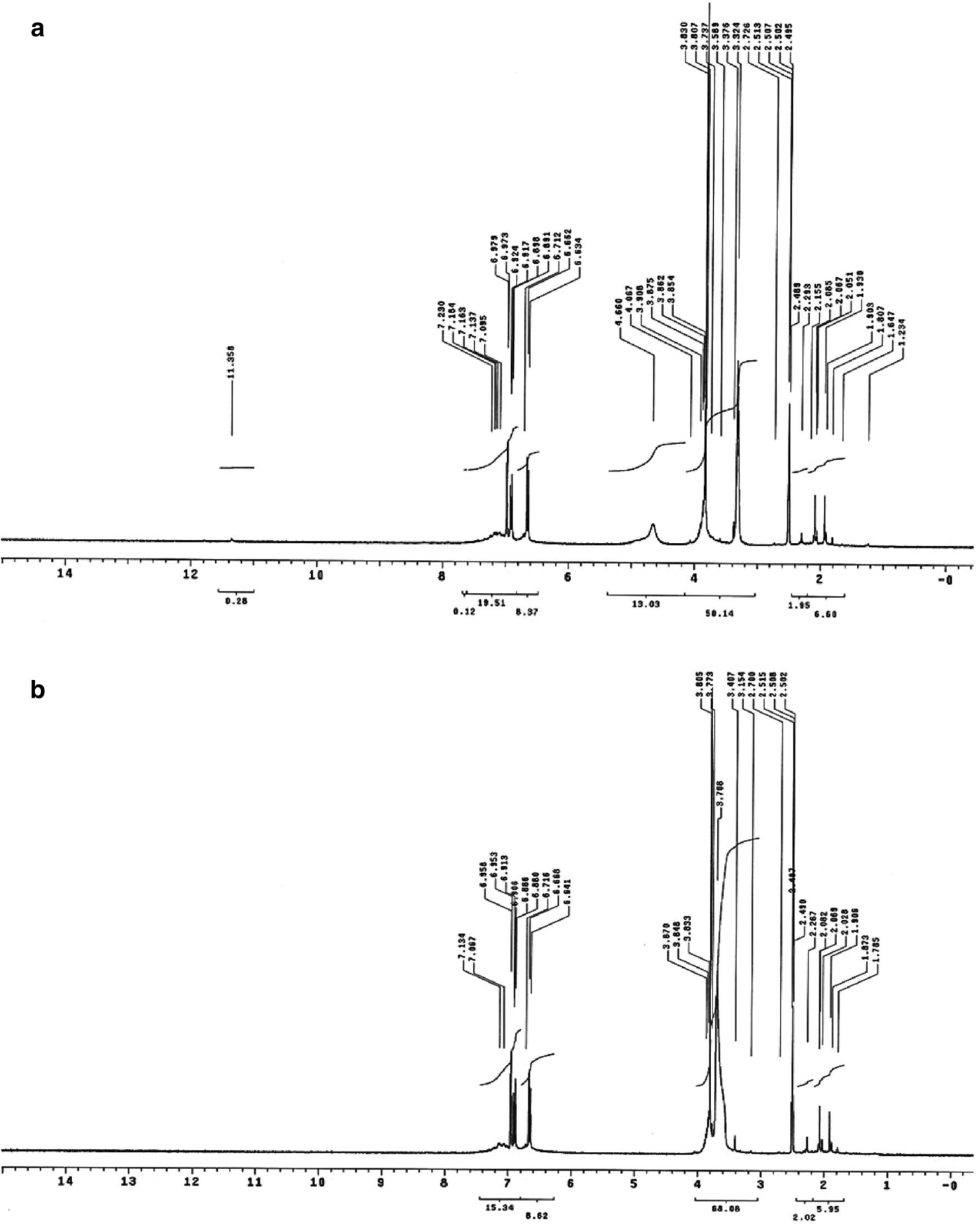

Fig. 2 a The ${ }^{1}$ HNMR Spectrum of $\mathbf{H}_{2} \mathbf{L}$ in (DMSO). b The ${ }^{1} \mathrm{HNMR}$ Spectrum of $\mathbf{H}_{\mathbf{2}} \mathbf{L}$ in (DMSO $+\mathrm{D}_{2} \mathrm{O}$ )

calculated according to the equation $g_{\text {av }}=1 / 3\left[g_{\|}+2 g_{\perp}\right]$. Complex 4 exhibits $g_{\|}<2.3$, suggesting covalent characters of the copper-ligand bonding in this complex [39]. From the observed trend $g_{\|}>g_{\perp}>2.0023$, it is clear that the unpaired electron lies predominantly in $d_{x^{2}-y^{2}}$ orbital, giving $2 \mathrm{~B}_{1 \mathrm{~g}}$ as the ground state [40]. The exchange interaction (axial) parameter $(G)$, calculated as $G=\left(g_{\|}-2.0023\right) /$ $\left(g_{\perp}-2.0023\right)$, and found for the present copper(II) complex as 7.3, suggests that the local tetragonal axes are aligned parallel and the exchange interactions between copper(II) centers in the solid state are negligible [41, 42]. The ESR spectral parameter of $\mathrm{Cu}(\mathrm{II})$ in complex has tetra hedral geometry around $\mathrm{Cu}(\mathrm{II})$ ions. These data are well consistent with other reported values [43]. 
Fig. 3 The mass spectrum of $\mathrm{H}_{2} \mathrm{~L}$

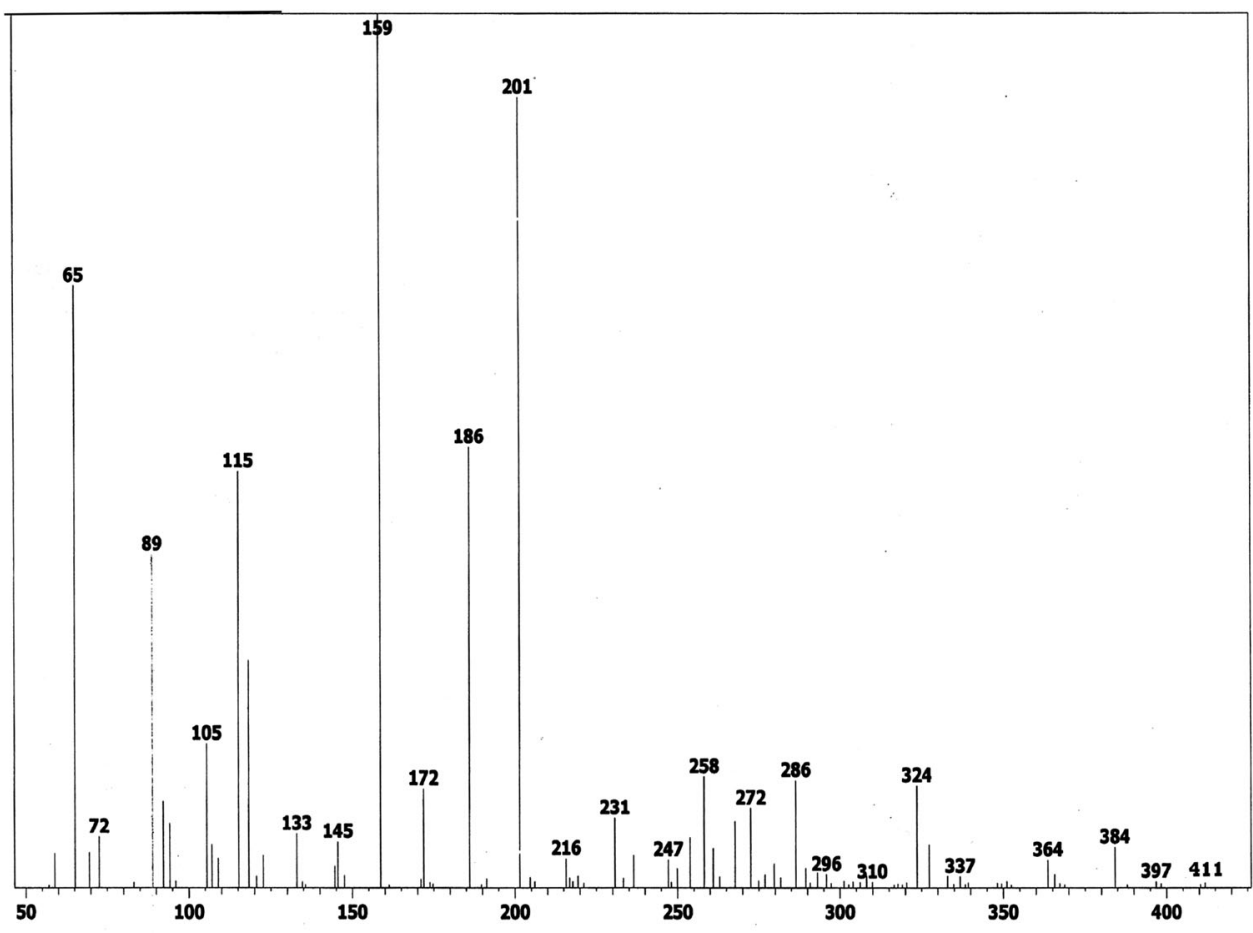

$\mathrm{CR}=W \cdot 534 / A \cdot d \cdot t$,

The thermo gravimetric analysis (TGA) curves for complexes were obtained at a heating rate of $10{ }^{\circ} \mathrm{C} / \mathrm{min}$ and flowing nitrogen atmosphere over a temperature range of room temperature $800{ }^{\circ} \mathrm{C}$ and the proposed decomposition data were recorded in Table 2. As examples, Figs. 6 and 7 show the thermograms obtained for complexes $\mathbf{2}$ and $\mathbf{3}$.

The first step with small mass losses occurs between 80 and $90{ }^{\circ} \mathrm{C}$, due to loss of outer sphere crystalline water. The removal of coordinated water molecules appeared at higher temperature $\left(>110-120{ }^{\circ} \mathrm{C}\right)$. The complexes show multi-step decomposition due to thermal degradation of organic part of ligands. The final weight loss matches with the formation of metal oxides as the stable end product.

From the thermogravimetric analysis, the overall weight losses for 2, 3, 4, and 5 complexes agree well with the proposed formula obtained by elemental analysis, IR, ${ }^{1} \mathrm{H}$, ${ }^{13} \mathrm{C}$ NMR, mass, ESR, and magnetic susceptibility measurements. The proposed structures as in Fig. 8 have been assigned for the metal complexes.

\subsection{Corrosion Inhibition Studies}

\subsubsection{Weight Loss Technique}

The corrosion rate (CR) in mils per year (MPY) and percentage corrosion inhibition efficiency (IE\% $=\mu_{\mathrm{w}} \%$ ) were calculated using the Eqs. (1) and (2), respectively [44]. where $W=$ weight loss $(\mathrm{g}), d=$ density of mild steel $\left(7.85 \mathrm{~g} / \mathrm{cm}^{3}\right), A=$ area of specimen (sq.cm), $T=$ exposure time (h).

$\mu_{\mathrm{w}} \%=\left(\left(C_{\mathrm{R}}^{0}-C_{\mathrm{R}}^{\mathrm{i}}\right) / C_{\mathrm{R}}^{0}\right) \times 100$,

where $C_{\mathrm{R}}^{0}$ and $C_{\mathrm{R}}^{\mathrm{i}}$ are the corrosion rates in absence and presence of inhibitors, respectively.

From the evaluated weight loss, surface coverage $(\theta)$ was calculated using Eq. (3):

$\theta=\left(C_{\mathrm{R}}^{0}-C_{\mathrm{R}}^{\mathrm{i}} / C_{\mathrm{R}}^{0}\right)$

The values of percentage inhibition efficiency $\left(\mu_{\mathrm{WL}} \%\right)$, corrosion rate (CR), and surface coverage $(\theta)$ obtained from weight loss method at different concentrations of all compounds at $293 \mathrm{~K}$ are summarized in Table 3 .

From the data, the Schiff base and its complexes show appreciable corrosion inhibition for carbon steel in $0.5 \mathrm{M} \mathrm{HCl}$ medium. The effect of inhibitor concentration on inhibition efficiency in the presence of different concentrations of the Schiff base and its complexes show that the maximum inhibition efficiency is at $7 \times 10^{-4} \mathrm{Mol} / \mathrm{dm}^{3}$ in $0.5 \mathrm{M} \mathrm{HCl}$ solution. The Co(II) complex 2 exhibited the greatest impact on corrosion inhibition among the other compounds as they appear in the chart (1). It was found that the efficiency order followed by compounds is $\mathbf{2}>\mathbf{3}>\mathbf{5}>\mathbf{1}>\mathbf{4}$.

In order to get good reproducibility, experiments were carried out from two to three times per test. In the present 


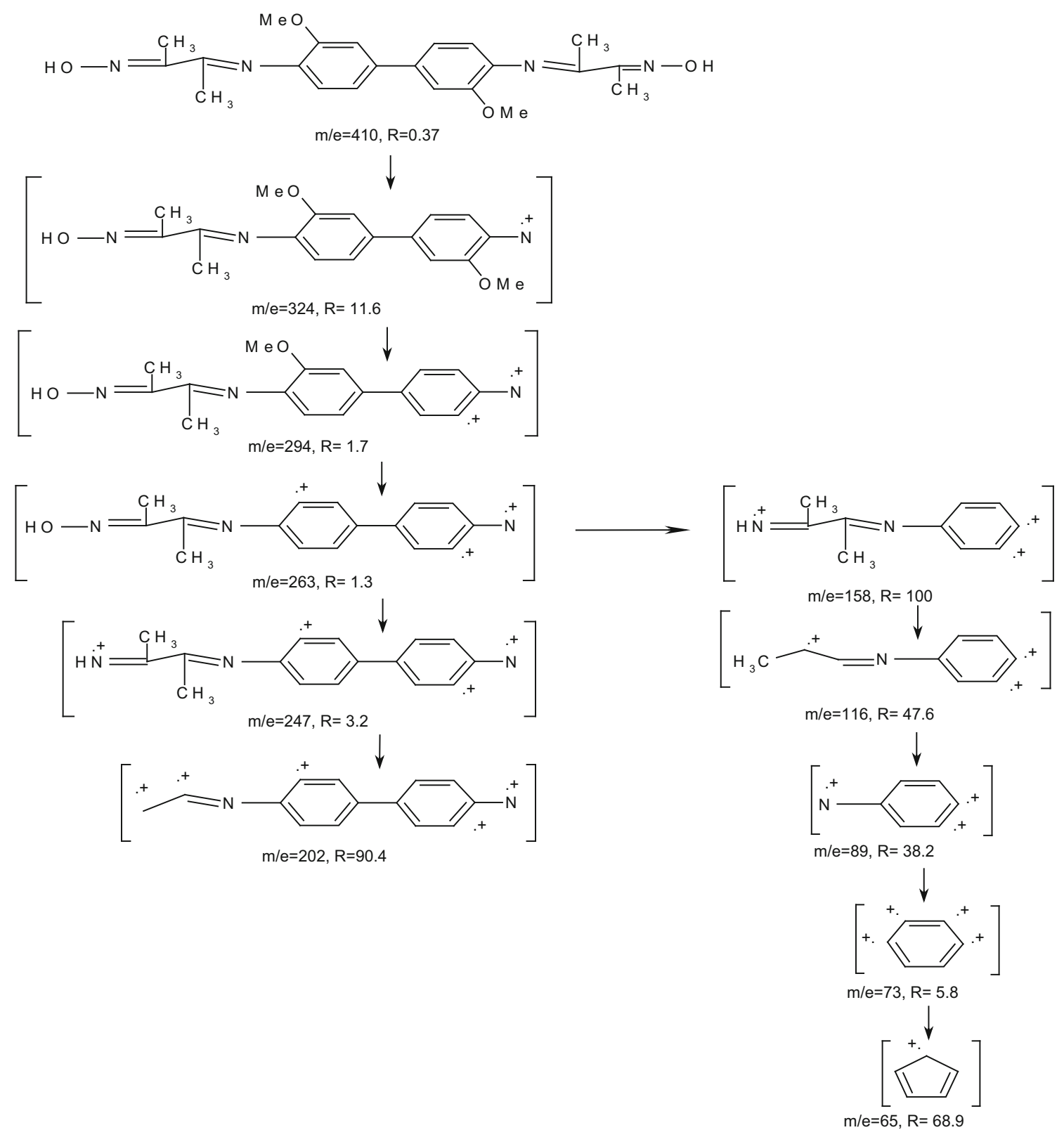

Scheme 1 The mass fragmentation pattern of Schiff base ligand $\mathbf{H}_{2} \mathbf{L}^{\mathbf{1}}$

Table 1 IR spectral data for compounds 1-5

\begin{tabular}{lrrrlllllr}
\hline Comp & $\mathrm{H}_{2} \mathrm{O}$ & $\mathrm{OH}$ & $\mathrm{CH}$ ar & $\mathrm{CH}$ aliph & $\mathrm{C}=\mathrm{N}$ & $v(\mathrm{~N}-\mathrm{O})$ oxime & $\mathrm{M}-\mathrm{O}$ & $\mathrm{M}-\mathrm{N}$ & $\mathrm{M}-\mathrm{Cl}$ \\
\hline $\mathbf{1}$ & - & 3441 & 3090 & 2860 & 1620 & 1030 & - & - & - \\
$\mathbf{2}$ & 3385 & - & 3022 & 2954 & 1608 & 1061 & 615 & 584 & 312 \\
$\mathbf{3}$ & 3377 & - & 3035 & 2934 & 1608 & 1060 & 660 & 615 & 316 \\
$\mathbf{4}$ & 3425 & - & 2920 & 2850 & 1598 & 1059 & 660 & 584 & 315 \\
$\mathbf{5}$ & 3488 & - & 3075 & 2925 & 1610 & 1063 & 660 & 589 & 318 \\
\hline
\end{tabular}

study, the standard deviation values among parallel test experiments were found to be smaller than $4 \%$, indicating good reproducibility. Also, we calculated some statistical analysis (Table 4) as mean, median, mode, standard deviation, minimum, and maximum values for each group to measure inhibition efficiency of compounds to corrosion of metals. From Table 4, we can obtain the minimum and maximum inhibition efficiencies of the compounds. The 
Fig. 4 Electronic spectrum of complex 2

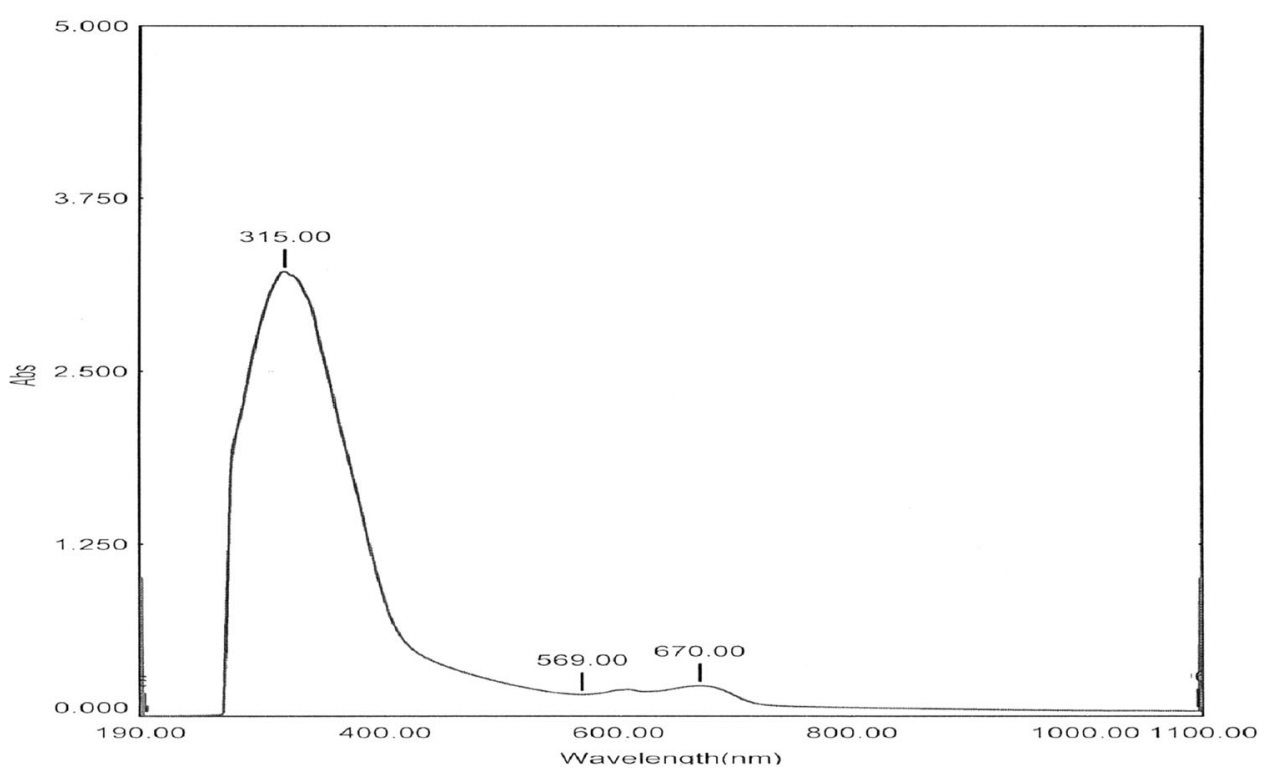

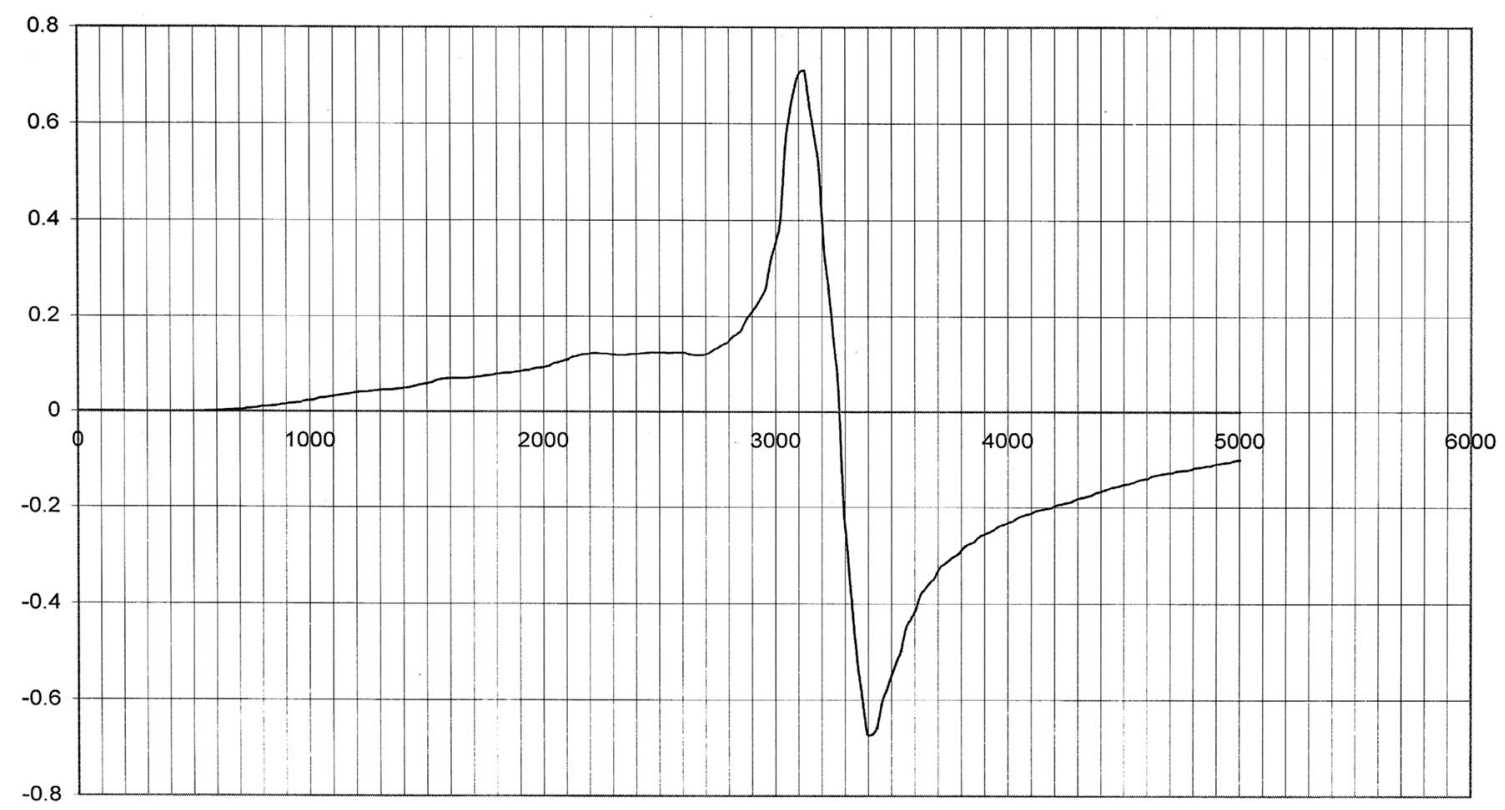

Fig. 5 ESR spectrum of $\mathrm{Cu}(\mathrm{II})$ complex 4

order of inhibition efficiency of compounds is the following: $\mathbf{2}>\mathbf{3}>\mathbf{5}>\mathbf{1}>\mathbf{4}$.

\subsubsection{Potentiodynamic Polarization}

The linear Tafel segments of anodic and cathodic curves were extrapolated to the corrosion potential to obtain corrosion current densities $\left(i_{\text {corr }}\right)$. From the polarization curves obtained, Figs. 9a-e, the corrosion current $\left(i_{\text {corr }}\right)$ was calculated by curve fitting using the Eqs. (4) and (5):
$I=i_{\text {corr }}\left[\exp \left(\frac{2.3 \Delta E}{b_{\mathrm{a}}}\right)-\exp \left(-\frac{2.3 \Delta E}{b_{\mathrm{c}}}\right)\right]$

The inhibition efficiency was evaluated from the measured $i_{\text {corr }}$ values using the relationship:

$\mu_{\mathrm{p}} \%=\frac{i_{\text {corr }}^{0}-i_{\text {corr }}^{\mathrm{i}}}{i_{\text {corr }}^{0}} \times 100$,

where $i_{\text {corr }}^{0}$ and $i_{\text {corr }}^{\mathrm{i}}$ are the corrosion current densities in the absence and presence of inhibitors, respectively. The electrochemical polarization parameters of steel corrosion 
Table 2 Thermal gravimetric analysis for compounds 2, 3, 4, and 5

\begin{tabular}{|c|c|c|c|c|c|c|}
\hline $\begin{array}{l}\text { Compound } \\
\text { no. }\end{array}$ & Stages & $\begin{array}{l}\text { Temp. range } \\
\left({ }^{\circ} \mathrm{C}\right)\end{array}$ & $\begin{array}{l}\text { Calculated } \\
\%\end{array}$ & $\begin{array}{l}\text { Found } \\
\%\end{array}$ & $\begin{array}{l}\text { Percent } \\
\text { error } \%\end{array}$ & Assignment \\
\hline \multirow[t]{5}{*}{2} & First step & $20-110$ & 15.90 & 15.30 & 3.9 & 2 Crystalline $\mathrm{H}_{2} \mathrm{O}+\mathrm{Cl}_{2}$ \\
\hline & Second step & $110-403$ & 21.70 & 21.30 & 1.9 & 2 Coordinated $\mathrm{H}_{2} \mathrm{O}+2 \mathrm{C}_{4} \mathrm{H}_{7}$ \\
\hline & Third step & $403-503$ & 13.70 & 12.80 & 7 & $2 \mathrm{NO}_{2}$ \\
\hline & Fourth step & $503-652$ & 26.00 & 23.50 & 10 & $\begin{array}{l}\text { Decomposition of organic part of ligand } \\
\left(2 \mathrm{C}_{7} \mathrm{H}_{6}\right)+\mathrm{N}_{2}+\mathrm{O}_{2}\end{array}$ \\
\hline & Residue & $652-800$ & 16.10 & 15.60 & 3.2 & $1.45 \mathrm{CoO}$ \\
\hline \multirow[t]{4}{*}{3} & First step & $20-120$ & 12.30 & 13.20 & -6.8 & 2 Crystalline $\mathrm{H}_{2} \mathrm{O}+\mathrm{NO}_{2}$ \\
\hline & $\begin{array}{l}\text { Second and Third } \\
\text { step }\end{array}$ & $120-482$ & 28.60 & 28.10 & 1.8 & 2 Coordinated $\mathrm{H}_{2} \mathrm{O}+\mathrm{NO}_{2}+2 \mathrm{C}_{4} \mathrm{H}_{7}$ \\
\hline & Fourth step & $482-660$ & 37.50 & 38.90 & -3.6 & $\begin{array}{l}\text { Decomposition of Organic part of ligand } \\
\left(2 \mathrm{C}_{7} \mathrm{H}_{6}\right)+\mathrm{Cl}_{2}\end{array}$ \\
\hline & Residue & $660-800$ & 20.00 & 19.60 & 2.0 & $1.8 \mathrm{NiO}$ \\
\hline \multirow[t]{5}{*}{4} & First step & $20-123$ & 5.30 & 5.30 & 0.0 & 2 Crystalline $\mathrm{H}_{2} \mathrm{O}$ \\
\hline & Second step & $123-242$ & 9.40 & 10.70 & -12.0 & 2 Coordinated $\mathrm{H}_{2} \mathrm{O}+\mathrm{N}_{2}$ \\
\hline & Third step & $242-374$ & 26.60 & 27.70 & -3.9 & $\begin{array}{l}\text { Decomposition of organic part of ligand } \\
\left(2 \mathrm{C}_{4} \mathrm{H}_{7}\right)+\mathrm{Cl}_{2}\end{array}$ \\
\hline & Fourth step & $374-623$ & 40.00 & 43.00 & -6.9 & $\begin{array}{l}\text { Decomposition of organic part of ligand } \\
\left(2 \mathrm{C}_{7} \mathrm{H}_{6}\right)+2 \mathrm{NO}_{2}\end{array}$ \\
\hline & Residue & $623-800$ & 14.00 & 13.00 & 7.6 & $1.25 \mathrm{CuO}$ \\
\hline \multirow[t]{5}{*}{5} & First step & $20-130$ & 13.00 & 12.40 & 4.8 & 1 Crystalline $\mathrm{H}_{2} \mathrm{O}+\mathrm{Cl}_{2}$ \\
\hline & Second step & $130-300$ & 7.90 & 8.90 & -11.2 & 1 Crystalline $\mathrm{H}_{2} \mathrm{O}+2$ Coordinated $\mathrm{H}_{2} \mathrm{O}+\mathrm{N}_{2}$ \\
\hline & Third step & $300-497$ & 13.4 & 13.5 & -0.7 & $2 \mathrm{NO}_{2}$ \\
\hline & Fourth step & $497-695$ & 51.20 & 54.00 & -5.2 & $\begin{array}{l}\text { Decomposition of Organic part of ligand }\left(2 \mathrm{C}_{7} \mathrm{H}_{6}\right) \& \\
\left(2 \mathrm{C}_{4} \mathrm{H}_{7}\right)+\mathrm{NO}\end{array}$ \\
\hline & Residue & $695-800$ & 13.00 & 12.00 & 4.8 & $1.1 \mathrm{ZnO}$ \\
\hline
\end{tabular}

in $0.5 \mathrm{M} \mathrm{HCl}$ in the presence and absence of various concentrations of Schiff base and its complexes and the corresponding corrosion efficiencies using Nova 1.10 program are given in Table 5.

The obtained results show that the inhibition efficiencies increase in the case of all used compounds when the inhibitor concentration increases. The efficiency order is as $\mathbf{2}>\mathbf{3}>\mathbf{5}>\mathbf{1}>\mathbf{4}$.

The results obtained from the polarization measurements are in good agreement with those obtained from the weight loss method and render to it. Also, addition of studied compounds effected both anodic and cathodic reactions. Therefore, those compounds could be classified as mixed type (anodic/cathodic) inhibitors.

\subsubsection{Adsorption Isotherm}

The increase in the inhibition efficiency of carbon steel in $0.5 \mathrm{M} \mathrm{HCl}$ solution, with increasing compound concentration can be explained on the basis of additive adsorption. In the present medium, the additives were shown the linear plots for $C / \theta$ versus Conc. and are suggested to obey the
Langmuir adsorption isotherm as seen in Fig. 10, according to the following Eq. (6):

$\theta /(1-\theta)=K C$,

where $\theta$ is the surface coverage, $C$ is concentration of inhibitors, and $K$ is the adsorption equilibrium constant which also represents the degree of adsorption (i.e., the higher value of $K$ indicate that inhibitor is strongly adsorbed on the metal surface); the $K$ obtained from the reciprocal of the intercept of Langmuir plot lines and the slope of these lines is near unity, meaning that each inhibitor molecule occupies one active site on the metal surface.

\subsubsection{Scanning Optical Microscope}

The optical images of carbon steel sample Fig. 11a shows degradation of carbon steel in the absence of inhibitors. The degradation appears more at grain boundary, since these regions are most susceptible to corrosion, and may be responsible for the high rate of corrosion. The optical images Figs. 11b-f of the carbon steel after corrosion in acid medium containing inhibitors show adsorbed layer of 
19 Page 10 of 16

J Bio Tribo Corros (2015) 1:19

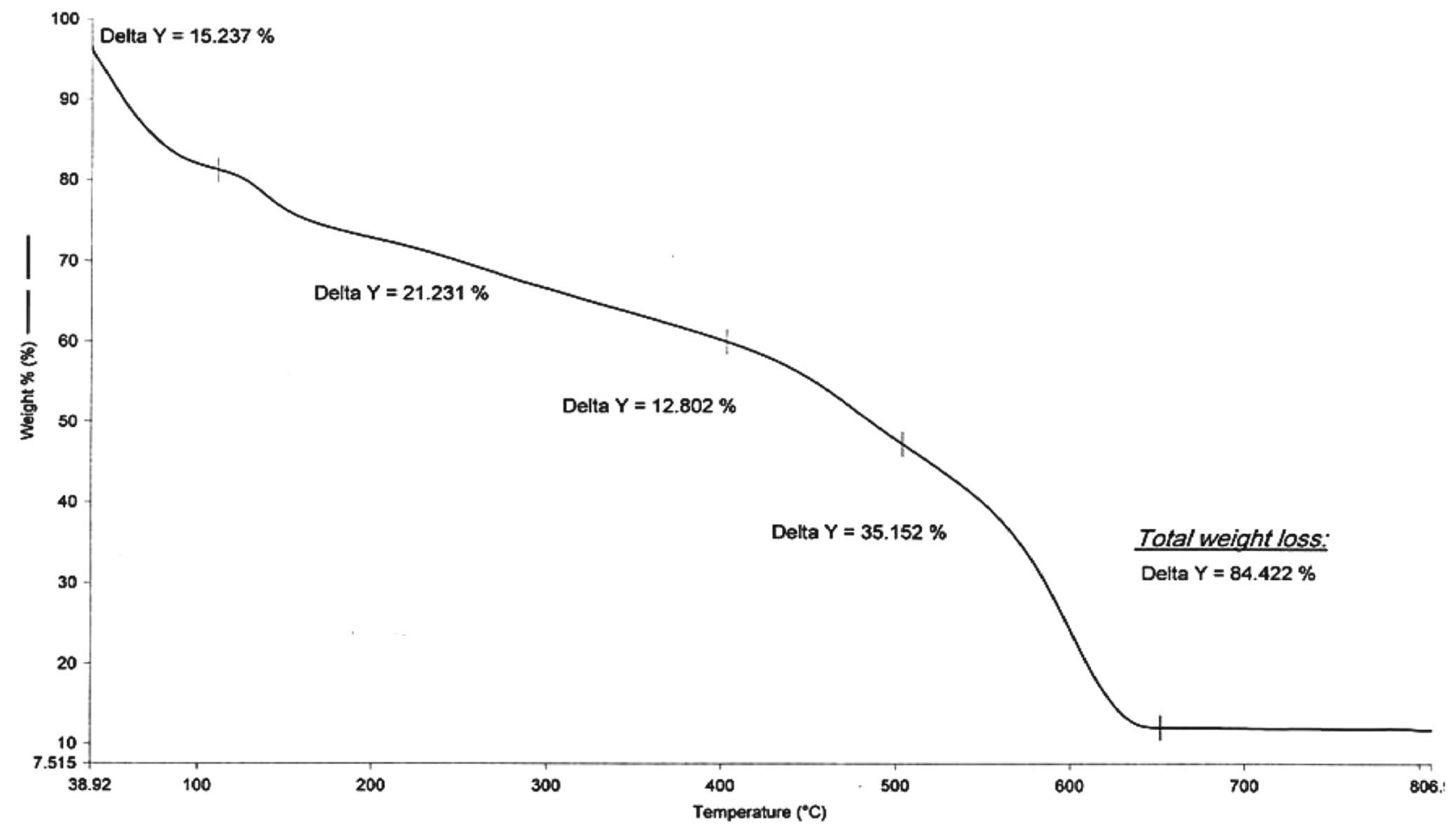

Fig. 6 TGA of complex 2

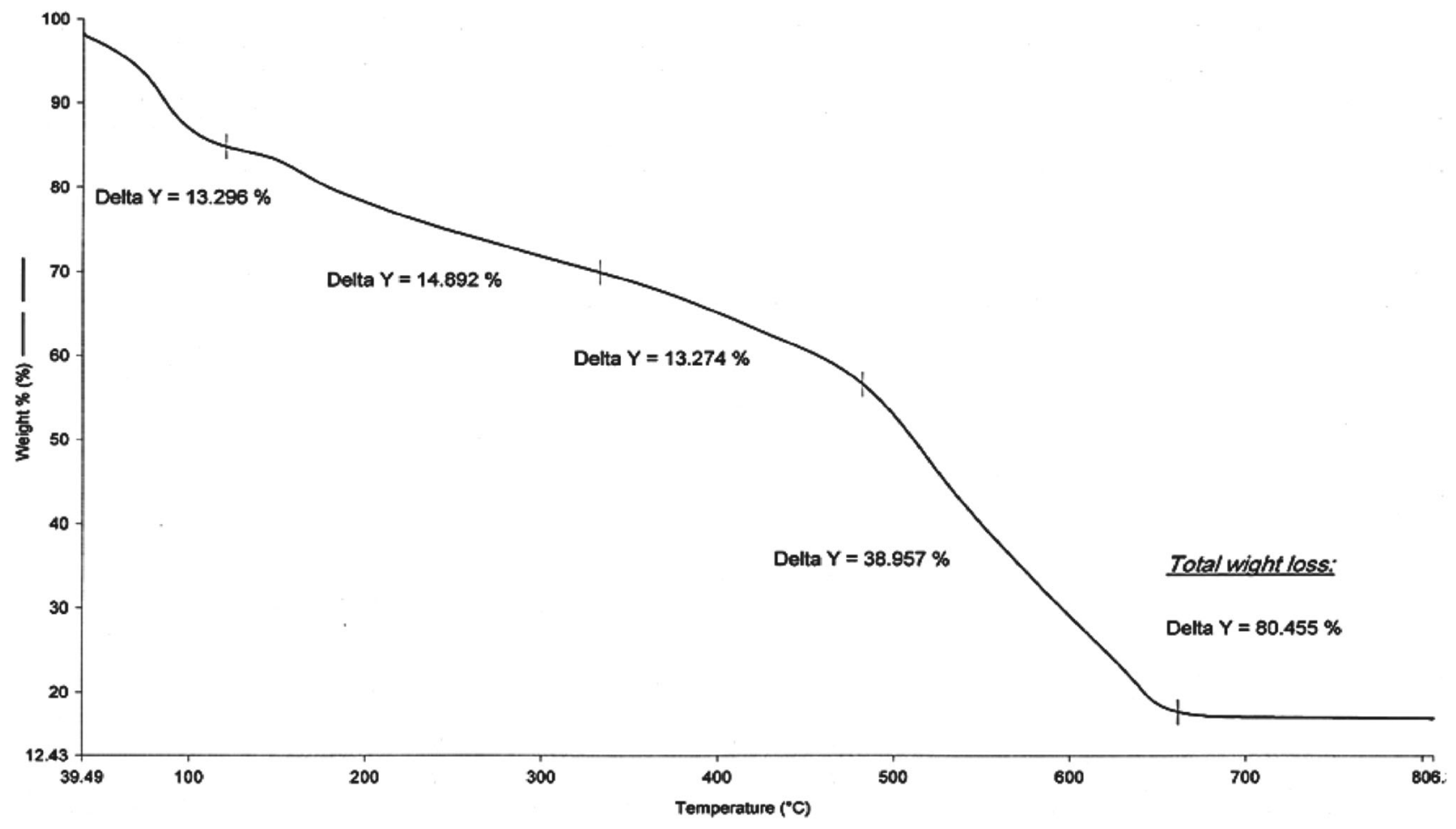

Fig. 7 TGA of complex 3

Springer 
inhibitor molecules on the metal surface, thus protecting the metal.

\subsubsection{Mechanism of Corrosion Inhibition}

The TGA results show that the compounds can be used as corrosion inhibitors under conditions that do not surpass $90{ }^{\circ} \mathrm{C}$ which is the onset temperature of the complexes

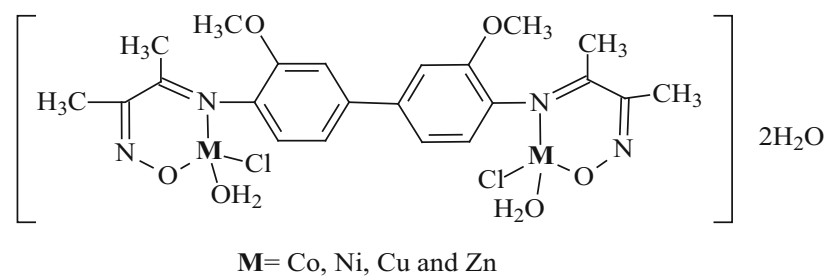

Fig. 8 The proposed structure of complexes 2-5 degradation. Increasing of temperature may lead to partial decomposition of the complexes. Also, it was reported that, the increasing of temperature caused the partial decomposition of the coating film and separated from carbon steel surface [45].

It can be seen from the data that the Schiff base $\left(\mathrm{H}_{2} \mathrm{~L}, 1\right)$ and its complexes exhibited good corrosion inhibition against corrosion of mild steel in acidic medium which may be attributed to the presence of $\pi$ electrons in aromatic systems and multiple bonds, presence of azomethine group, and the electronegative atoms $(\mathrm{O}$ and $\mathrm{N})$ In the inhibitor molecules structures [46]. The effect of additional methoxy substituent groups on the aromatic ring. The methoxy group exhibits an inductive effect that results in the increase of the electron density and the activation of the aromatic ring, which may impact better absorptivity to the inhibitor which improve adsorption and protection. This suggests that corrosion inhibition is a result of adsorption surface coverage, and inhibition efficiency values for the corrosion of mild steel in aqueous solution of $0.5 \mathrm{M} \mathrm{HCl}$ in the absence and in the presence of different concentrations of different inhibitors from weight loss measurements
Table 3 The corrosion rate,

\begin{tabular}{lllll}
\hline Compound & Concentration $(\mathrm{M})$ & CR $(\mathrm{mm} / \mathrm{year})$ & $\theta$ & IE\% \\
\hline Blank & $0.5 \mathrm{M} \mathrm{HCl}$ & 0.0035 & - & - \\
$\mathbf{1}$ & 0.0001 & 0.000874011 & 0.728374 & 72.83737 \\
& 0.0003 & 0.000768239 & 0.761246 & 76.12457 \\
& 0.0005 & 0.000462057 & 0.856401 & 85.64014 \\
$\mathbf{2}$ & 0.0007 & 0.000395254 & 0.877163 & 87.71626 \\
& 0.0001 & 0.000740405 & 0.769896 & 76.98962 \\
& 0.0003 & 0.000718137 & 0.776817 & 77.68166 \\
& 0.0005 & 0.000292265 & 0.90917 & 90.91696 \\
$\mathbf{3}$ & 0.0007 & 0.000208761 & 0.935121 & 93.51211 \\
& 0.0001 & 0.000896279 & 0.721453 & 72.14533 \\
& 0.0003 & 0.00064855 & 0.798443 & 79.84429 \\
& 0.0005 & 0.000489892 & 0.847751 & 84.77509 \\
& 0.0007 & 0.000211544 & 0.934256 & 93.42561 \\
$\mathbf{4}$ & 0.0001 & 0.00099116 & 0.688581 & 68.85813 \\
& 0.0003 & 0.000613968 & 0.807093 & 80.70934 \\
& 0.0005 & 0.00058093 & 0.817474 & 81.7474 \\
& 0.0007 & 0.000528618 & 0.83391 & 83.391 \\
& 0.0001 & 0.000578176 & 0.818339 & 81.83391 \\
& 0.0003 & 0.000481814 & 0.848616 & 84.86159 \\
& 0.0005 & 0.000371685 & 0.883218 & 88.3218 \\
& 0.0007 & 0.000294595 & 0.907439 & 90.74394 \\
& & &
\end{tabular}

Table 4 Some statistical analysis for $1,2,3,4$, and 5 compounds for studying the inhibition efficiency of corrosion of metal in acid medium by weight loss method

\begin{tabular}{lllllll}
\hline Compound & Mean & Median & Mode & SD & Minimum value & Maximum value \\
\hline $\mathbf{1}$ & 80.6 & 80.8 & $72.8,76.1,85.6,87.7$ & 7.2 & 72.8 & 87.7 \\
$\mathbf{2}$ & 84.7 & 84.3 & $76.9,77.6,90.9,93.5$ & 8.6 & 76.9 & 93.5 \\
$\mathbf{3}$ & 82.5 & 82.3 & $72.1,79.8,84.7,93.4$ & 8.9 & 72.1 & 93.4 \\
$\mathbf{4}$ & 78.6 & 81.2 & $68.8,80.7,81.7,83.3$ & 6.6 & 68.8 & 83.3 \\
$\mathbf{5}$ & 86.4 & 86.5 & $81.8,84.8,88.3,90.7$ & 3.9 & 81.8 & 90.7 \\
All compounds & 82.6 & 82.6 & - & 7.1 & 68.8 & 93.5 \\
\hline
\end{tabular}



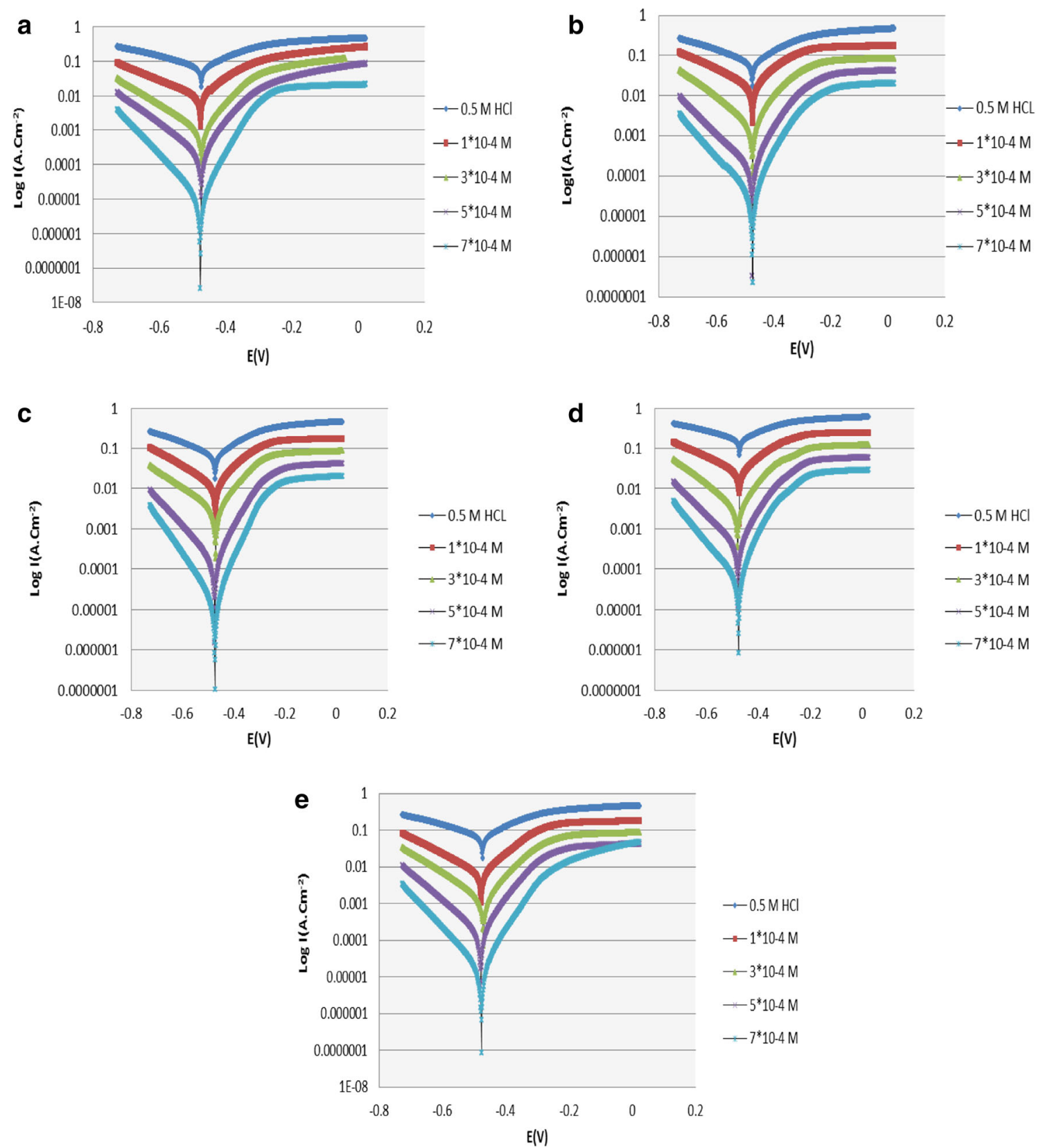

Fig. 9 Polarization curves for mild steel in the presence of different concentrations of compounds 1 (a), 2 (b), 3 (c), 4 (d), and 5 (e)

of inhibitors on the metal surface and the compounds act as adsorption inhibitors. Also, it should be emphasized that, the large size and high molecular weight of the compounds can contribute to the greater inhibition efficiency.

\subsection{Antibacterial Activity}

Sulfate-reducing bacteria (SRB) are commonly considered the main culprits of microbially influenced corrosion (MIC) due to their characteristic corrosion product iron sulfide which are ubiquitously associated with anaerobic corrosion damage. The results of antibacterial activity of
Schiff base ligand $\mathbf{H}_{2} \mathbf{L}$ and its complexes against (SRB)stabilized mixed culture are clear in Fig. 12. The antibacterial activity tests were carried out in four concentrations 100, 300, 500, and 700 ppm and showed a good antibacterial activity. The most active compound comparison with other is $\mathbf{4}$ which is followed by $\mathbf{2}$ and $\mathbf{5}$. From the results, the antibacterial activity was increased with the increasing concentration of compounds and the lowest concentration of 4 with a good antimicrobial activity is $300 \mathrm{ppm}$. The results revealed that the $\mathrm{SRB}$ activity was less inhibited using compound $\mathbf{1}$. The antibacterial activity of compounds due to the interaction of biocides with surface cell causes 
Table 5 Polarization parameters of Schiff base $\mathbf{H}_{2} \mathrm{~L}$ and its complexes

\begin{tabular}{lllllclc}
\hline Comps. & Conc. & $b_{\mathrm{a}}$ & $b_{\mathrm{c}}$ & $E_{\text {corr. }}$ & $I_{\text {corr. }}$ & CR & IE\% \\
\hline $\mathbf{1}$ & Blank & 47.6 & 71.3 & -478.3 & 119.34 & 0.9236 & - \\
& $1 \times 10^{-4}$ & 48.6 & 56.5 & -490.0 & 19.54 & 0.1175 & 83.6 \\
& $3 \times 10^{-4}$ & 32.0 & 32.9 & -492.9 & 16 & 0.1129 & 86.5 \\
& $5 \times 10^{-4}$ & 16.3 & 14.2 & -493.6 & 13.9 & 0.802 & 88.6 \\
& $7 \times 10^{-4}$ & 18.46 & 14.6 & -481.6 & 11.34 & 0.1079 & 90.5 \\
$\mathbf{2}$ & Blank & 55.8 & 71.9 & -479.0 & 246.8 & 1.90 & - \\
& $1 \times 10^{-4}$ & 24.4 & 19.9 & -495.3 & 43.2 & 0.3349 & 82.4 \\
& $3 \times 10^{-4}$ & 35.9 & 42.7 & -494.1 & 39.7 & 0.3082 & 83.8 \\
& $5 \times 10^{-4}$ & 42.7 & 59.2 & -440.2 & 27.4 & 0.3179 & 88.8 \\
& $7 \times 10^{-4}$ & 35.3 & 35.7 & -442.5 & 21.0 & 0.1965 & 91.4 \\
& Blank & 47.6 & 71.3 & -478.3 & 119.34 & 0.9236 & - \\
& $1 \times 10^{-4}$ & 21.8 & 17.4 & -463.9 & 25.6 & 0.1577 & 78.5 \\
& $3 \times 10^{-4}$ & 13.44 & 17.03 & -446.6 & 20.6 & 0.1985 & 82.7 \\
& $5 \times 10^{-4}$ & 22.9 & 13.6 & -450.6 & 10.6 & 0.8 & 91.1 \\
& $7 \times 10^{-4}$ & 19.5 & 16.6 & -452 & 6.8 & 0.05 & 94.3 \\
& Blank & 47.6 & 71.3 & -478.3 & 119.34 & 0.9236 & - \\
& $1 \times 10^{-4}$ & 40.5 & 32.6 & -472.9 & 27.6 & 0.2140 & 76.8 \\
& $3 \times 10^{-4}$ & 37.4 & 47.6 & -464.5 & 24.8 & 0.1866 & 79.8 \\
& $5 \times 10^{-4}$ & 44.7 & 48.9 & -459.0 & 21.14 & 0.1638 & 82.2 \\
& $7 \times 10^{-4}$ & 34.04 & 38.6 & -453.4 & 19.4 & 0.1476 & 84.0 \\
& Blank & 47.6 & 71.3 & -478.3 & 119.3 & 0.9236 & - \\
& $1 \times 10^{-4}$ & 57.6 & 90.4 & -458.2 & 27.6 & 0.2142 & 76.8 \\
& $3 \times 10^{-4}$ & 40.9 & 47.2 & -468.7 & 26.33 & 0.2040 & 77.9 \\
& $5 \times 10^{-4}$ & 30.46 & 29.90 & -463.3 & 15.45 & 0.1197 & 87.5 \\
& $7 \times 10^{-4}$ & 30.27 & 30.30 & -453.3 & 11.37 & 0.0881 & 90.4 \\
\hline & & & & & & &
\end{tabular}

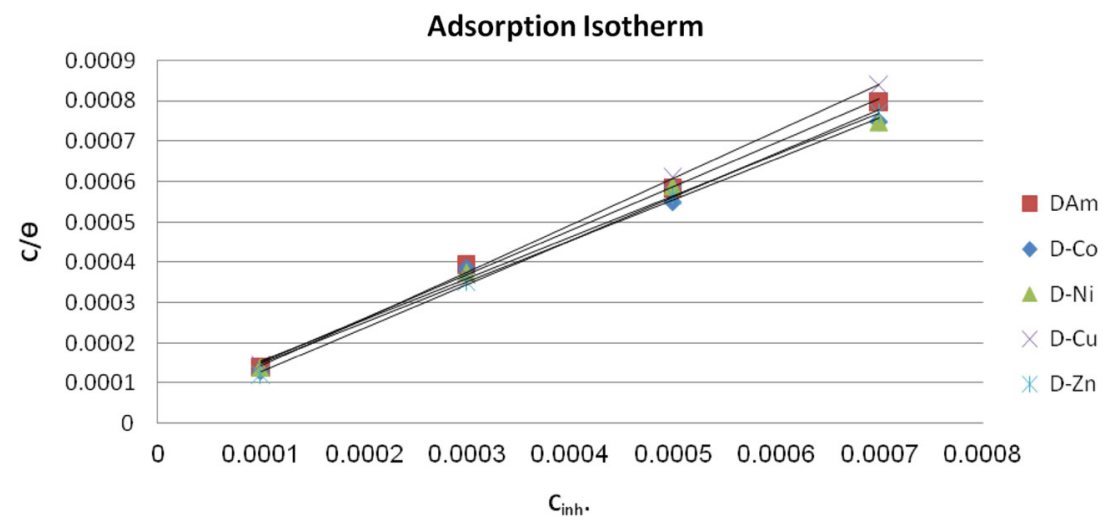

Fig. 10 Langmuir isotherm of $\mathbf{H}_{2} \mathbf{L}$ and its complexes at $20^{\circ} \mathrm{C}$ on carbon steel surface destruction of the microstructure of the cell wall and the cytoplasmic membrane $[47,48]$.

\subsubsection{Mechanism of Antimicrobial Activity}

Schiff bases having chelation with oxygen, nitrogen donors, and their complexes have been used as drugs and possess a wide variety of biological activities against bacteria, fungi, and certain types of tumors and also, they have many biochemical, clinical, and pharmacological properties due to the presence of azomethine group $(-\mathrm{N}=\mathrm{CH}-)$ which imports in elucidating the mechanism of transformation and racemization reaction biologically. In general in this work, the metal chelates show higher antimicrobial activity than the parent Schiff base. The good antimicrobial activity of metal complexes than Schiff base ligand is due to chelation theory [49], which suggests that the chelation process increases the delocalization of the $\pi$-electrons over the whole chelate ring, which results in an increase in the lipophilicity of the metal complexes. 

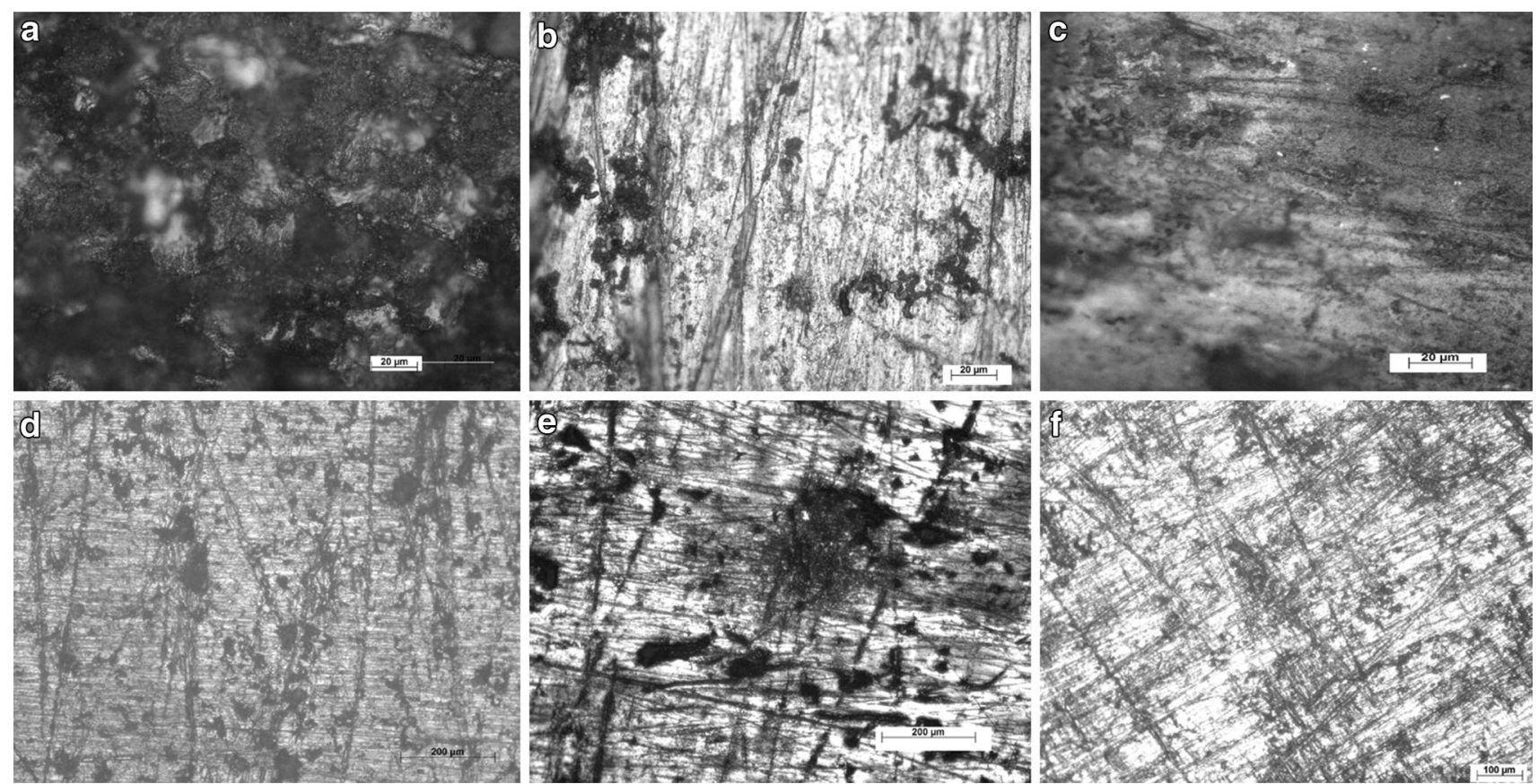

Fig. 11 Optical microscope images of carbon steel sample in acid medium without inhibitor (a), and with inhibitors $\mathbf{H}_{2} \mathbf{L}^{\mathbf{1}}(\mathbf{b}), \mathbf{2}$ (c), $\mathbf{3}(\mathbf{d}), \mathbf{4}(\mathbf{e})$, and 5 (f)

Fig. 12 The inhibition efficiency of different concentrations from Schiff base (1) and its complexes (2-5) in $0.5 \mathrm{M} \mathrm{HCl}$ solution

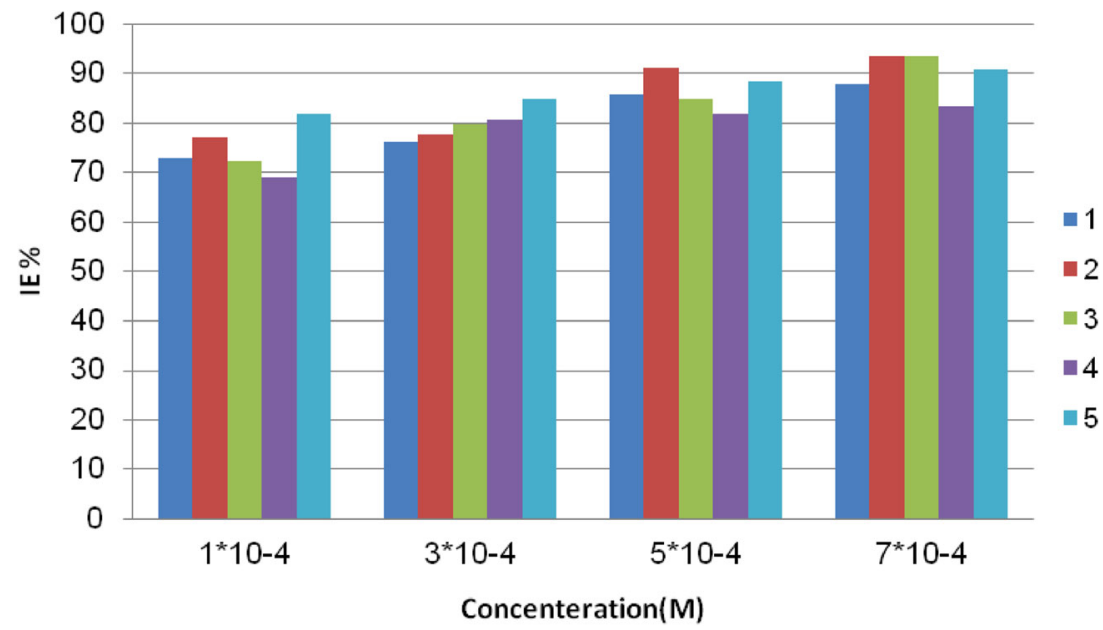

Consequently, the metal complexes can easily penetrate into the lipid membranes and block the metal binding sites of enzymes of the microorganisms. These metal complexes also affect the respiration process of the cell and thus block the synthesis of proteins, which restricts further growth of the organism.

\section{Conclusion}

New homobimetallic complexes with Schiff base Bis(diacetylmonoxime)biphenyl-3,3'-dimethoxy-4, $4^{\prime}$-diamine were prepared and investigated. The structure of the ligand and its complexes were determined by elemental analysis, magnetic moment, and mass, UV, IR, ${ }^{1} \mathrm{H}$ NMR, ${ }^{13} \mathrm{C}$ spectra. The Schiff base and its complexes were tested as corrosion inhibitors and fined as mixed type inhibitors as evident from the weight loss and potentiodynamic polarization techniques. The inhibitor efficiencies of compounds increase with increasing concentration of the compounds. The order of inhibition efficiency follows the following pattern $\mathbf{2}>\mathbf{3}>\mathbf{5}>\mathbf{1}>\mathbf{4}$, due to increasing of the molecular weight of compounds. The inhibitors obey Langmuir adsorption isotherm. Also, the optical microscope images revealed protection of metal surface in the $\mathrm{HCl}$ medium by the adsorption of inhibitors on the surface of the metal. The 
synthesized compounds appeared a good antibacterial activity against SRB which can cause corrosion. Finally, the synthesized compounds can be used in double purpose as corrosion inhibitors and as biocides.

Acknowledgments The authors are thankful to Dr. Ahmed Ismail in CMRDI for his assistance in taking optical microscope images. Also, we thankful Dr. Musttfa Abo El Soud in National Research Center for his assistance in antibacterial activity analysis.

\section{References}

1. Sun W, Nesic S (2007) A mechanistic model of $\mathrm{H}_{2} \mathrm{~S}$ corrosion of mild steel, NACE International corrosion conference \& Expo. Houston, Texas, USA, paper No. 07655, (2007)1-26.

2. Tao Z, Zhang S, Li W, Hou B (2009) Corrosion inhibition of mild steel in acidic solution by some oxo-triazole derivatives. Corros Sci 51:2588-2595

3. Trabanelli G (1991) Inhibitors-an old remedy for a new challenge. Corrosion 47:410-419

4. Raman A, Labine P (1986) Reviews on Corrosion Inhibitor Science and Technology, vol 1. NACE, Houston, p 5

5. Hosseini MG, Mertens SFL, Ghorbani M, Arshadi MR (2003) Asymmetrical Schiff bases as inhibitors of mild steel corrosion in sulfuric acid media. Mater Chem Phys 78:800-808

6. Singh AK, Quraishi MA (2010) Effect of Cefazolin on the corrosion of mild steel in $\mathrm{HCl}$ solution. Corros Sci 52:152-160

7. Singh AK, Quraishi MA, Ebenso EE (2011) Inhibitive effect of cefuroxime on the corrosion of mild steel in hydrochloric acid solution. Int J Electrochem Sci 6:5673-5688

8. Singh AK, Quraishi MA (2012) Study of some bidentate schiff bases of isatin as corrosion inhibitors for mild steel in hydrochloric acid solution. Int J Electrochem Sci 7:3222-3241

9. Shokry H, Yuasa M, Sekine I, Issa RM, El Baradie HY, Gomma GK (1998) Corrosion inhibition of mild steel by schiff base compounds in various aqueous solutions. Corros Sci 40: 2173-2186

10. Emregül KC, Atakol O (2003) Corrosion inhibition of mild steel with schiff base compounds in $1 \mathrm{M} \mathrm{HCl}$. Mater Chem Phys 82:188-193

11. Kumar A (2013) Corrosion resistance properties of benzhydrylidene-(3, 5-dimethoxy-phenyl)-amine on mild steel in 0. 5M sulphuric acid media. Int J Chem Appl 5:191-197

12. Emregül KC, Kurtaran R, Atakol O (2003) An investigation of chloride-substituted Schiff bases as corrosion inhibitors for steel. Corros Sci 45:2803-2817

13. Li S, Chen S, Lei S, Ma H, Yu R, Liu D (1999) Investigation on some Schiff bases as $\mathrm{HCl}$ corrosion inhibitors for copper. Corros Sci 41:1273-1287

14. Agrawal YK, Talati JD, Shah MD, Desai MN, Shah NK (2004) Schiff bases of ethylenediamine as corrosion inhibitors of zinc in sulphuric acid. Corros Sci 46:633-651

15. Mahdavian M, Attar MM (2009) Electrochemical behaviour of some transition metal acetylacetonate complexes as corrosion inhibitors for mild steel. Corros Sci 51:409-414

16. Poornima T, Nayak J, Shetty AN (2012) Effect of diacetyl monoxime thiosemicarbazone on the corrosion of aged $18 \mathrm{Ni} 250$ grade maraging steel in sulphuric acid solution. J Metall 2012: $1-13$

17. Hamilton WA (1985) Sulphate-reducing bacteria and anaerobic corrosion. Annu Rev Microbiol 39:195-217

18. Javaherdashti R, Raman SRK, Panter C, Pereloma EV (2006) Microbiologically assisted stress corrosion cracking of carbon steel in mixed and pure cultures of sulfate reducing bacteria. Biodegradation 58:27-35

19. Azzam EMS, Sami RM, Kandile NG (2012) Activity inhibition of sulfate reducing bacteria using some cationic thiol surfactants and their nanostructures. Am J Biochem 2:29-35

20. Vester F, Ingvorsen K (1998) Improved most-probable-number method to detect sulfate-reducing bacteria with natural media and a radiotracer. Appl Environ Microbiol 64(5):1700-1707

21. Nassar AM, Hassan AM, Ibraheem NM, Hekal BH (2015) Synthesis and comparative studies of cyclopalladated complexes With ortho $\mathrm{C}-\mathrm{H}$ activation of aromatic rings bearing electron donating and electron withdrawing groups. Synth React Inorg Met Org Nano Met Chem 45:813-820

22. Nonyama M, Tomita S, Yamasaki K (1975) N(2-pyridyle)acetamide complexes of metal ions. Inorg. Chim Acta 12:33-37

23. Bullock JI, Tajmir-Riahi HA (1978) Schiff-base complexes of the lanthanoids and actinoids. Part 1. Lanthanoid(III) halide complexes with the un-ionised form of $\mathrm{NN}^{\prime}$-ethyl-enebis(salicylideneimine) and related bases. J Chem Soc Dalton Trans 1:36-39

24. Rakha TH (1999) Mononuclear and binuclear chelates of biacetylmonoxime picolinoylhydrazone. Trans Met Chem 24: 659-665

25. Teixeira LHP, Fraga CAM, Barreiro EJ (1998) Synthesis of new 1,2-benzothiazin-3-one derivatives, designed as dual cyclooxigenase and 5-lipooxigenase inhibitors candidates. J Braz Chem Soc 9:119-130

26. Lin-Vien D, Clothup NB, Fateley WG, Grasselli JG (1991) The hand book of infrared and Raman chracteristic frequencieis of organic molecules. Academic Press, San Diego

27. Nassar AM, Hassan AM, Al-Abd SS (2015) Antitumor and antimicrobial activities of novel palladacycles with abnormal aliphatic C-H activation of Schiff Base 2-[(3-phenylallylidene)amino] phenol. Synth React Inorg Met Org Nano Met Chem 45:256-270

28. Mobinikhaledi A, Forughifar N, Kalhor M (2010) An efficient synthesis of Schiff bases containing benzimidazole moiety catalyzed by transition metal nitrates. Turk J Chem 34:367-373

29. Anupama B, Kumari CG (2013) Cobalt (II) complexes of ONO donor Schiff bases and N, N donor ligands: synthesis, characterization, antimicrobial and DNA binding study. Int J Res Chem Environ 3:172-180

30. Ummathur MB, Sayudevi P, Krishnankutty K (2009) Schiff bases of 3-[2-(1,3-benzothiazol-2-yl)hydrazinylidene] pentane-2,4dione with aliphatic diamines and their metal complexes. J Arg Chem Soc 97:31-39

31. Karvembu R, Hemalatha S, Prabhakaran R, Natarajan K (2003) Synthesis, characterization and catalytic activities of ruthenium complexes containing triphenylphosphine/triphenylarsine and tetradentate Schiff bases. Inorg Chem Commun 6:486-490

32. Aliyu HN, Mohammed AS (2009) Synthesis and characterization of Iron (II) and Nickel (II) Schiff base complexes. Bajopas 2:132-134

33. Krushnalal TJ, Pancholi AM, Pandaya KS, Thakar AS (2011) Synthesis, characterization and antibacterial activity of novel schiff base derived from 4-acetyl-3-methyl-1-(4'-methyl- phenyl)-2-pyrazolin-5-one and its transition metal complexes. J Res Chem Environ 1:63-69

34. Budagumpia S, Shetti UN, Kulkarnia NV, Revankara VK (2009) Ligational behaviour of bidentate coumarin derivative towards $\mathrm{Co}(\mathrm{II}), \mathrm{Ni}(\mathrm{II})$ and $\mathrm{Cu}(\mathrm{II})$ synthesis, characterization, electrochemistry and antimicrobial studies. J Coord Chem 62: 3961-3968

35. Spinu C, Kriza A (2000) $\mathrm{Co}(\mathrm{II}), \mathrm{Ni}(\mathrm{II})$, and $\mathrm{Cu}(\mathrm{II})$ complexes of bidentate Schiff bases. Acta Chim Slov 47:179-185

36. Raman N, Raja YP, Kulandaisamy A (2001) Synthesis and characterisation of $\mathrm{Cu}(\mathrm{II}), \mathrm{Ni}(\mathrm{II}), \mathrm{Mn}(\mathrm{II}), \mathrm{Zn}(\mathrm{II}($, and $\mathrm{VO}(\mathrm{II})$ 
Schiff base complexes derived from o-phenylenediamine and acetoacetanilide. Indian Acad Sci 113(2001):183-189

37. Rehman S, Ikram M, Islam N, Jan N (2011) Synthesis and characterization of $\mathrm{Ni}(\mathrm{II}), \mathrm{Cu}(\mathrm{II})$ and $\mathrm{Zn}$ (II) tetrahedral transition metal complexes of modified hydrazine. J Mex Chem Soc 55: 164-167

38. Liang YM, Liu CM, Ma YX (1998) formyl ferrocene 5-phenyloxazole-2-carbonylhydrazone bivalent transition-metal complexes. Trans Met Chem 23:97-99

39. Lever ABP (1984) Inorganic electronic spectroscopy, 2nd edn. Elsevier, New York

40. Speir G, Csihony J, Whalen AM, Pierpont CG (1996) Studies on aerobic reactions of ammonia/3,5-Di-tert-butylcatechol Schiffbase condensation products with $\mathrm{Cu}, \mathrm{Cu}(\mathrm{I})$, and $\mathrm{Cu}(\mathrm{II})$. Strong $\mathrm{Cu}$ (II)-radical ferromagnetic exchange and observations on a unique N-N coupling reaction. Inorg Chem 35:3519-3524

41. Hathaway BJ, Bardley JN, Gillard RD (1971) Essays in chemistry. Academic Press, New York

42. Hathway BJ (1984) Structure and Bonding. Springer, Berlin 57:55-118
43. Jeyasubramanian K, Thambidurai S, Ramalingam S, Murugesan $R$ (1998) Spectral and redox models for blue copper proteins: copper(II) complexes of $\beta$-diketonimines from a Knoevenagel condensate. J Inorg Biochem 72:101-107

44. Narayan R (1983) An introduction to metallic corrosion and its prevention, 1st edn. Oxford and IBH, Oxford

45. Bahkahk CK, Hadi JS (2015) New unsymmetrical Schiff base as inhibitor of carbon steel corrosion and antibacterial activity. Res J Chem Sci 5(1):64-70

46. Singh AK, Quraishi MA (2012) Study of some bidentate schiff bases of isatin as corrosion inhibitors for mild steel in hydrochloric acid solution. Int J Electrochim Sci 7:3222-3241

47. American Public Health Association (APHA) (1989) Stander methods for the examination of water and waste water, $17 \mathrm{th}$ edn. APHA, New York

48. Ghazy EA, Eweas AF (2006) Microbial corrosion of mild steel and its inhibition. Chem A 3:321-327

49. Jejurkar CR, Parikh K (1997) Synthesis and characterization of Schiff base complexes of Copper(II), Nickel(II), Vanduim(IV), and Uranium(VI). Asian J Chem 9:624-629 